\title{
Soft Clay Treatment Using Geo-Foam Beads and Bypass Cement Dust
}

\author{
Mahmoud Samir El-kady ${ }^{1,2 *}$ and Essam Farouk Badrawi ${ }^{1,3}$ \\ ${ }^{1}$ Faculty of Engineering, Department of Structural Engineering, Zagazig University, Egypt \\ ${ }^{2}$ Department of Civil Engineering, Jouf University, Kingdom of Saudi Arabia \\ ${ }^{3}$ Department of Civil Engineering Department, University of Business and Technology, Kingdom of Saudi Arabia
}

Submission: October 01, 2018; Published: December 12, 2018

*Corresponding author: Mahmoud Samir El-kady, Department of Civil Engineering Jouf University, Kingdom of Saudi Arabia

\begin{abstract}
Soft clays are usually classified according to their undrained shear strength, $\mathrm{Cu}$. Values of $\mathrm{Cu}$ less than $12.5 \mathrm{kPa}$ are associated with very soft clays, whereas, soft clays possess undrained shear strength ranging between $12.5 \mathrm{kPa}$ and $25 \mathrm{kPa}$. In addition to the low shear strength of soft clays, they experience high compressibility upon loading. This is why soft clays are considered as problematic for foundation purposes. Also, Geo-foam is an industrial material, characterized by a very low unit weight (average of $20 \mathrm{~kg} / \mathrm{m} 3$ ) compared to that of the soil. Having a density ranging from $1.0 \%$ to $2.5 \%$ of that of soil EPS possesses a compressive strength ranging between $70 \mathrm{kPa}$ and $140 \mathrm{kPa}$ and an elastic modulus ranging between 5MPa and 12MPa, According to Horvath (1997). EPS Geo-foam blocks are used in a wide range of geotechnical applications as a light weight fill.

So, the main objective of this study is to investigate the geotechnical properties of soft clay with Geo-foam beads and bypass cement dust. Also, investigate the possibility of preparing low strength excavatable fill mixtures. For studying the effect of (Geo-foam beads + CBPD) / soft clay on fluid-state and hardened properties of new fill, experimental work was carried out on two groups of mixture (A\&B). Different ratios of (Geofoam beads + CBPD) were added to the mixture to study its effect on flow consistency, dry unit weight, unconfined compressive strength, and shear strength. The results of test conducted on the materials illustrated that, cement bypass dust and excess foundry sand can be successfully used to procedure self-compaction, self-leveling excavatable flowable fill material. The unconfined compressive strength of the studied mixtures without Geo-foam ranged between $271.8 \mathrm{kPa}$ and $1405.14 \mathrm{kPa}$ at CBPD between $3.88 \%$ and $18.63 \%$. The Cohesion values for group with Geofoam with ranged between $50 \mathrm{kPa}$ and $20 \mathrm{kPa}$ at Geo-foam between $0.32 \%$ and $1.35 \%$. The friction angle of group with Geo-foam with ranged between 10 and $22 \mathrm{kPa}$ at CBPD between $0.32 \%$ and $1.35 \%$.
\end{abstract}

Keywords: Geo-foam Beads; Bypass Cement Dust; Flowable Fill; Shear Strength

\section{Introduction}

EPS Geo-foam blocks are used in a wide range of geotechnical applications as a light weight fill. The primary function of Geofoam is to provide a lightweight void fill below a highway, bridge approach, embankment or parking lot [1]. EPS Geo-foam minimizes settlement on underground utilities. Geo-foam is also used in much broader applications, the major ones being as lightweight fill, green roof fill, compressible inclusions, thermal insulation, and (when appropriately formed) drainage. Expanded polystyrene (EPS) Geo-foam has been used as a geotechnical material since the 1960s. EPS Geo-foam is approximately $1 \%$ the weight of soil and less than $10 \%$ the weight of other lightweight fill alternatives. As lightweight fill, EPS Geo-foam reduces the loads imposed on adjacent and underlying soils and structures [3].
EPS Geo-foam is not a general soil fill replacement material but is intended to solve engineering challenges. The use of EPS typically translates into benefits to construction schedules and lowers the overall cost of construction because it is easy to handle during construction, often without the need for special equipment, and is unaffected by occurring weather conditions [3]. EPS Geo-foam can be used to replace compressible soils or in place of heavy fill materials to prevent unacceptable loading on underlying soils and adjacent structures. The high compressive resistance of EPS Geo-foam makes it able to adequately support traffic loadings associated with secondary and interstate highways [4]. Also, using EPS Geo-foam eliminates the need for compaction and fill testing, reduces the construction time and minimizes impact to the existing roadway and adjacent 


\section{Civil Engineering Research Journal}

structures and/or buried utilities [5]. Experimental work was carried out on two groups of mixture (A\&B) and different ratios of (Geo-foam beads + CBPD) were added to the mixture to study its effect on the geotechnical properties.

\section{Experimental Program}

\section{Material characteristics}

The soft clay was dried in the oven at $110^{\circ} \mathrm{C}$. It is passing through sieve size of $0.25 \mathrm{~mm}$. Soft clay characteristics are listed in Table 1.
Table 1: Properties of tested soft clay soil.

\begin{tabular}{|c|c|}
\hline Soft clay properties & Value \\
\hline Average liquid limit, \% & 48 \\
\hline Average plastic limit, \% & 26 \\
\hline Plasticity index, \% & 22 \\
\hline Soft clay type (A-line chart) & CI \\
\hline
\end{tabular}

Also, the unit weight of the Geo-foam beads is $15.0 \mathrm{~kg} / \mathrm{m} 3$ The size of the Geo-foam beads is $5.0 \mathrm{~mm}$ Figure $1 \mathrm{a}$.

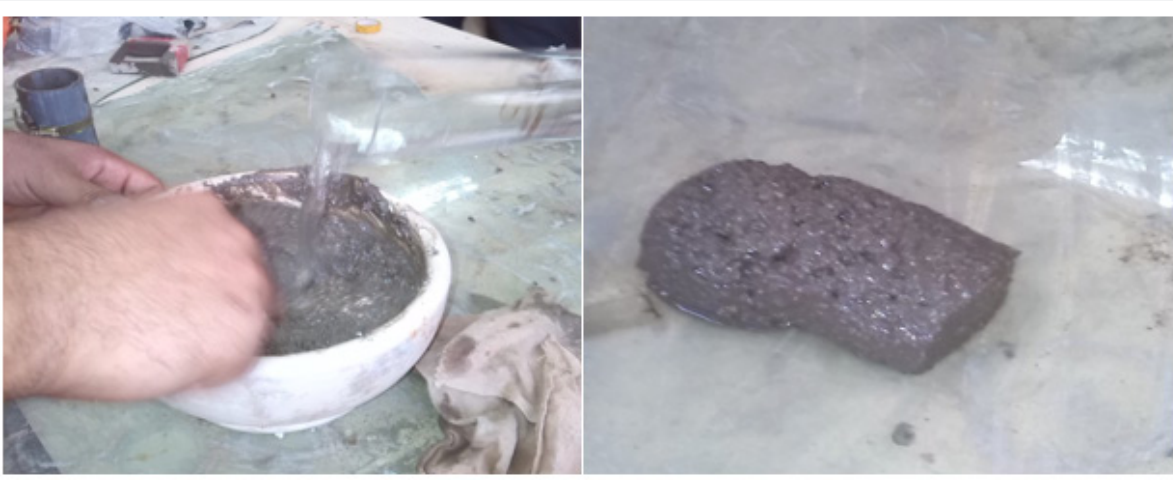

Figure 1: Mixing the samples.

\section{Mixture proportions}

The experimental work was divided into two groups, each with the same size of $600 \mathrm{~cm} 3$. Group A was divided into five subsamples without the use of Geo-foam and mixed with increasing percentages of CBPD (50g) for each sample and different percentages of water. In addition, the B group was divided into five sub-samples and mixed with increasing percentages of Geo-foam (5g) for each sample as well as different percentages of water with stable weight of CBPD as shown in the following Tables 2-5.

Table 2

\begin{tabular}{|c|c|c|c|c|c|}
\hline \multirow{2}{*}{ Group } & Mix & $\begin{array}{c}\text { Soft clay } \\
\text { (gm) }\end{array}$ & $\begin{array}{c}\text { CBPD } \\
\text { (gm) }\end{array}$ & $\begin{array}{c}\text { Geo-foam } \\
\text { (gm) }\end{array}$ & $\begin{array}{c}\text { Water } \\
\text { (gm) }\end{array}$ \\
\hline \multirow{4}{*}{$\mathrm{A}$} & $\mathrm{A} 1$ & 1000 & 50 & 0 & 240 \\
\cline { 2 - 6 } & $\mathrm{A} 2$ & 1000 & 100 & 0 & 250 \\
\cline { 2 - 6 } & $\mathrm{A} 3$ & 1000 & 150 & 0 & 250 \\
\cline { 2 - 6 } & $\mathrm{A} 4$ & 1000 & 200 & 0 & 260 \\
\cline { 2 - 6 } & $\mathrm{A} 5$ & 1000 & 300 & 0 & 310 \\
\hline
\end{tabular}

Table 3

\begin{tabular}{|c|c|c|c|c|c|}
\hline \multirow{2}{*}{ Group } & Mix & Soft Clay, \% & CBPD (\%) & $\begin{array}{c}\text { Geo-foam } \\
\text { (\%) }\end{array}$ & $\begin{array}{c}\text { water } \\
\text { (\%) }\end{array}$ \\
\hline \multirow{3}{*}{ A } & A1 & 77.52 & 3.88 & 0 & 18.6 \\
\cline { 2 - 6 } & A2 & 74.07 & 7.41 & 0 & 18.52 \\
\cline { 2 - 6 } & A3 & 71.43 & 10.71 & 0 & 17.86 \\
\cline { 2 - 6 } & A4 & 68.49 & 13.7 & 0 & 17.81 \\
\cline { 2 - 6 } & A5 & 62.11 & 18.63 & 0 & 19.25 \\
\hline
\end{tabular}

Table 4

\begin{tabular}{|c|c|c|c|c|c|}
\hline Group & Mix & $\begin{array}{c}\text { Soft Clay } \\
\text { (gm) }\end{array}$ & $\begin{array}{c}\text { CBPD } \\
\text { (gm) }\end{array}$ & $\begin{array}{c}\text { Geo-foam } \\
\text { (gm) }\end{array}$ & $\begin{array}{c}\text { Water } \\
\text { (gm) }\end{array}$ \\
\hline \multirow{4}{*}{ B } & B1 & 1000 & 200 & 5 & 340 \\
\cline { 2 - 6 } & B2 & 1000 & 200 & 10 & 320 \\
\cline { 2 - 6 } & B3 & 1000 & 200 & 15 & 400 \\
\cline { 2 - 6 } & B4 & 1000 & 200 & 20 & 450 \\
\cline { 2 - 6 } & B5 & 1000 & 200 & 25 & 640 \\
\hline
\end{tabular}

Tables 5: Grouping of tested mix samples.

\begin{tabular}{|c|c|c|c|c|c|}
\hline Group & Mix & $\begin{array}{c}\text { Soft Clay, } \\
\text { \% }\end{array}$ & CBPD (\%) & $\begin{array}{c}\text { Geo-foam } \\
\text { (\%) }\end{array}$ & $\begin{array}{c}\text { water } \\
\text { (\%) }\end{array}$ \\
\hline \multirow{4}{*}{ B } & B1 & 64.72 & 12.94 & 0.32 & 22.01 \\
\cline { 2 - 6 } & B2 & 65.36 & 13.07 & 0.65 & 20.92 \\
\cline { 2 - 6 } & B3 & 61.92 & 12.38 & 0.93 & 24.77 \\
\cline { 2 - 6 } & B4 & 59.88 & 11.98 & 1.2 & 26.95 \\
\cline { 2 - 6 } & B5 & 53.62 & 10.72 & 1.34 & 34.32 \\
\hline
\end{tabular}

Experimental Work and Results

\section{Flow consistency}

Samples were mixed for groups A-B for different percentages of water as shown in Figure 1b. The consistency flow of the samples was measured for each sample. It is found that the flow consistency increased slightly for group B than for group A. So, the flow consistency was measured in laboratory as listed in (Tables 6-7 ) for the two groups. Although the percentage of water present in the B samples, the effect of the presence of Geofoam beads than bypass cement dust on soil was clear as shown in Figure 2. 


\section{Civil Engineering Research Journal}

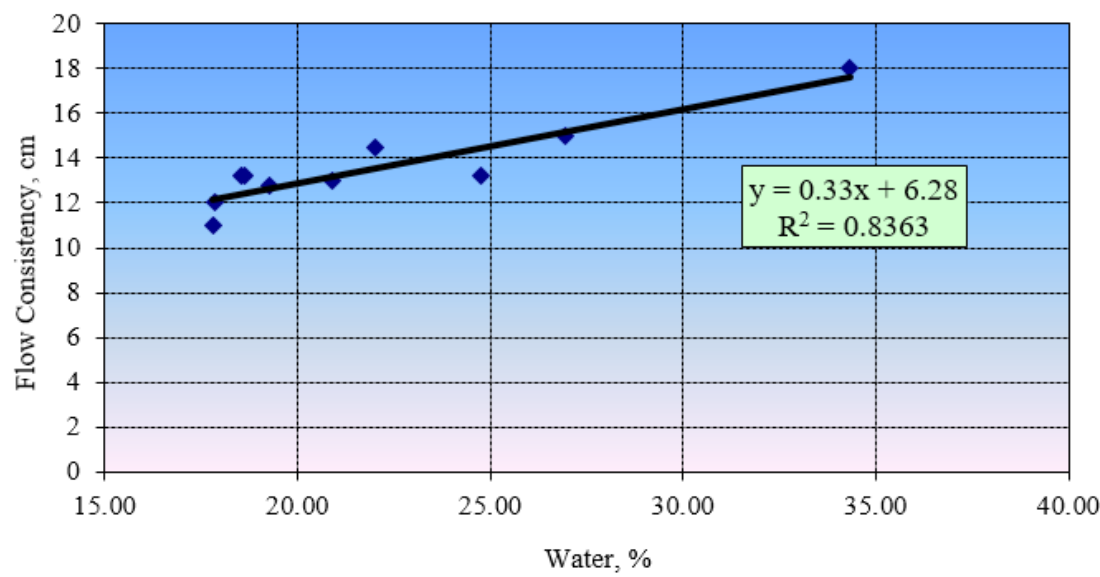

Figure 2: Flow consistency for group (B).

Table 6: Measurements of flow consistency (Group A).

\begin{tabular}{|c|c|c|c|}
\hline Group & Mix & Water (gm) & Flow Consistency, cm \\
\hline \multirow{4}{*}{ A } & A1 & 240 & 13.25 \\
\cline { 2 - 4 } & A2 & 250 & 13.25 \\
\cline { 2 - 4 } & A3 & 250 & 12 \\
\cline { 2 - 4 } & A4 & 260 & 11 \\
\cline { 2 - 4 } & A5 & 310 & 12.75 \\
\hline
\end{tabular}

Table 7: Measurements of flow consistency (Group B).

\begin{tabular}{|c|c|c|c|}
\hline Group & Mix & Water (gm) & Flow Consistency, cm \\
\hline \multirow{4}{*}{ B } & B1 & 340 & 14.5 \\
\cline { 2 - 4 } & B2 & 320 & 13 \\
\cline { 2 - 4 } & B3 & 400 & 13.25 \\
\cline { 2 - 4 } & B4 & 450 & 15 \\
\cline { 2 - 4 } & B5 & 640 & 18 \\
\hline
\end{tabular}

\section{Unconfined compressive strength}

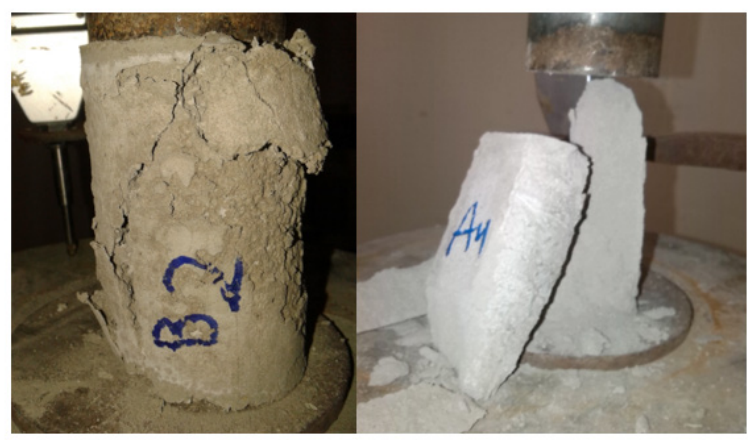

Figure 3: Typical shear failure of mixtures.

The studied mixtures for each group were molded and hardened. Unconfined compressive strength was obtained by the Triaxial test for the studied mixtures as shown in Figures 3. It was found that with the increase of cement bypass dust, the unconfined compressive strength increased significantly and especially for the samples (A4 - A5) compared to a slight increase in the values of the strain\% as shown in Figure 4. Also, compressive strength values are also stabilized with increasing mixing rates in cement bypass dust from approximately 14 to $18 \%$ as shown in Figure 5. This shows the significant effect of cement bypass dust on compressive strength of studied samples.

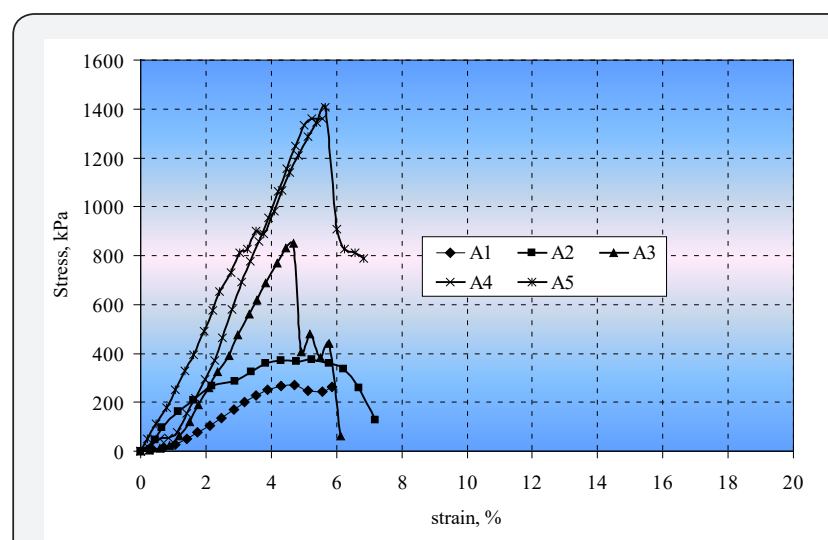

Figure 4: Typical stress-strain curve for group (A) samples.

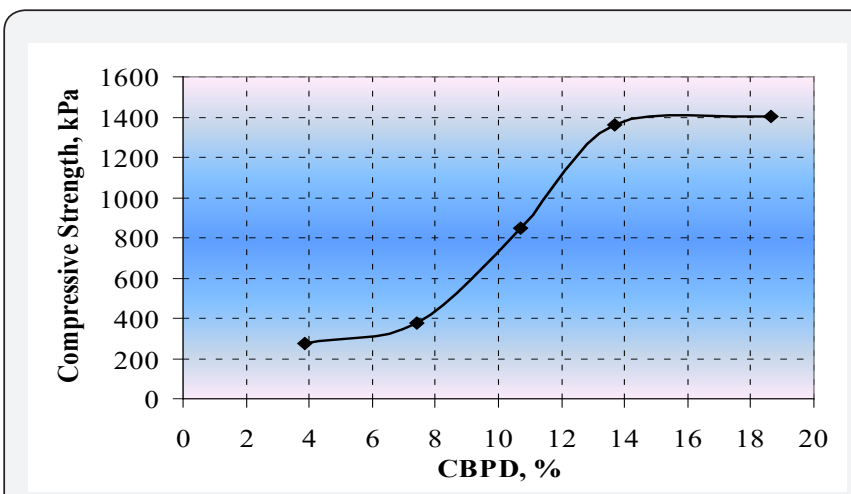

Figure 5: Effect of cement bypass dust on compressive strength.

\section{Shear strength}

Shear box test was carried out on the studied samples. The samples were loaded with increasing stresses (50-100-150kPa) 


\section{Civil Engineering Research Journal}

and the shear stresses were calculated versus horizontal displacement (mm). We took samples (A4-B4) for examples as shown in Figures 6-7. Shear strength parameters were obtained from direct shear test and it is concluded that CBPD affected in the cohesion of the group A samples as shown in Figure 8. On the contrary, angle of internal friction was increased significantly when increasing the ratio of Geo-foam beads for group B samples as shown in Figure 9 [6-10].

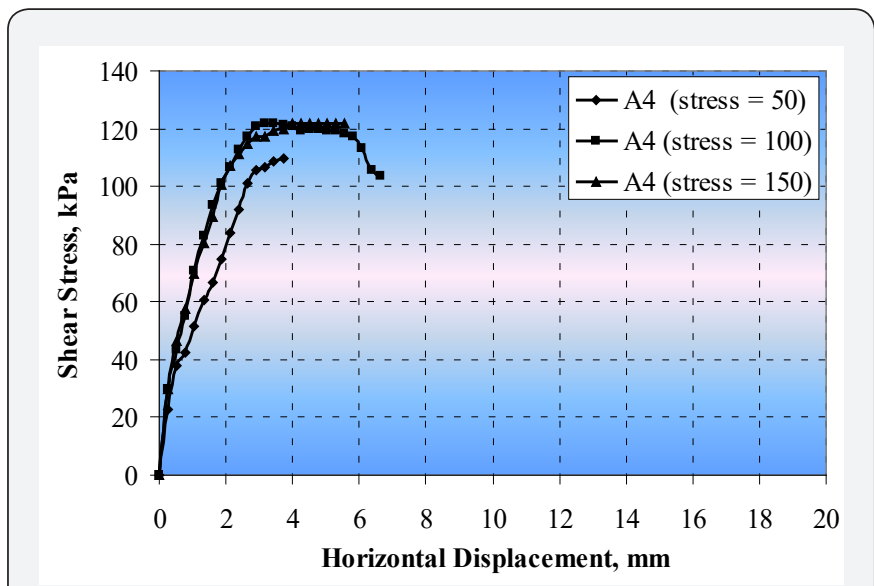

Figure 6: Shear strength versus horizontal displacement for (A4).

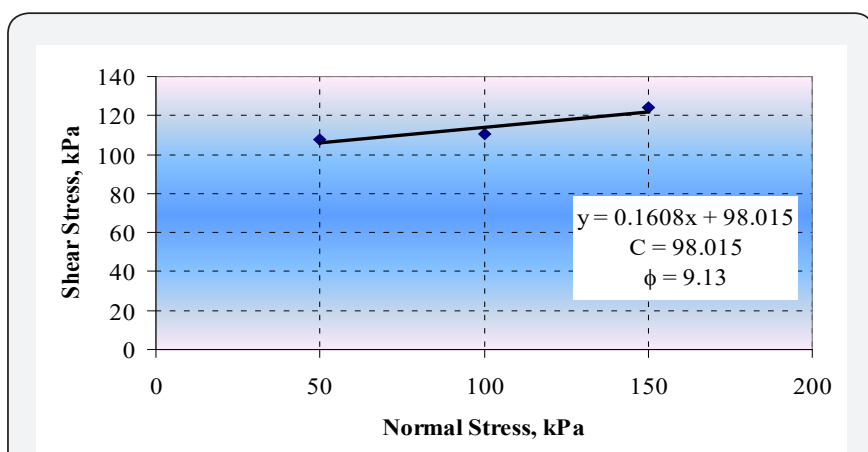

Figure 7:Shear strength parameters for sample (A4).

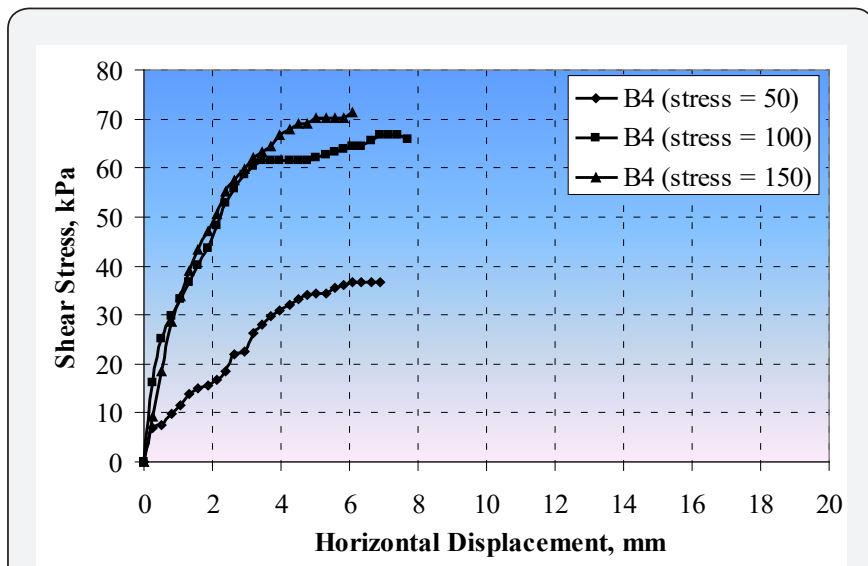

Figure 8: Shear strength versus horizontal displacement for (B4).

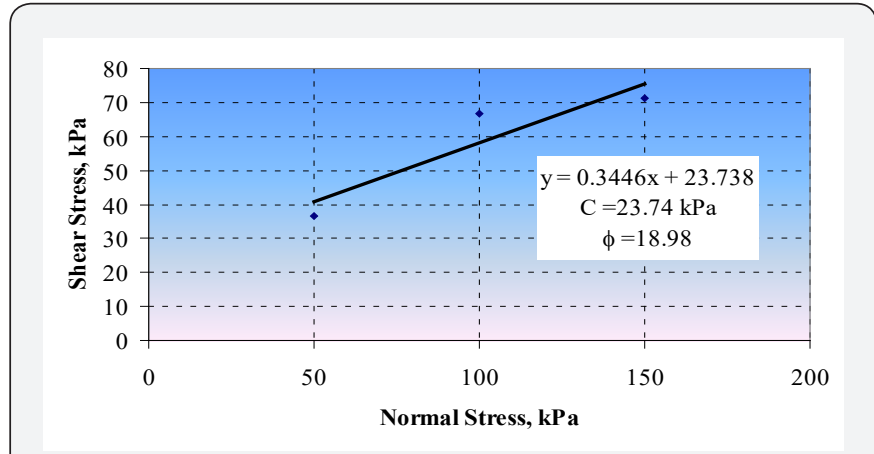

Figure 9: Shear strength parameters for sample (B4).

\section{Conclusion}

This paper presented an experimental study of various samples of soft clay mixed with different percentages of Geofoam beads and cement bypass dust. The following conclusions may be drawn:

A. The results of test conducted on the materials illustrated that, cement bypass dust and excess foundry sand can be successfully used to procedure self-compaction, selfleveling excavatable flowable fill material.

B. The dry unit weight of the studied mixtures for group without Geo-foam ranged between 1.40 and $1.6 \mathrm{gm} / \mathrm{cm} 3$ at CBPD between $3.88 \%$ and $18.63 \%$.

C. The dry unit weight of the studied mixtures for group with Geo-foam ranged between 0.65 and $1.20 \mathrm{gm} / \mathrm{cm} 3$ at Geo-foam between $0.32 \%$ and $1.35 \%$.

D. The unconfined compressive strength of the studied mixtures without Geo-foam ranged between $271.8 \mathrm{kPa}$ and $1405.14 \mathrm{kPa}$ at CBPD between $3.88 \%$ and $18.63 \%$.

E. The unconfined compressive strength of the studied mixtures with Geo-foam ranged between $230 \mathrm{kPa}$ and $120 \mathrm{kPa}$ at Geo-foam between $0.32 \%$ and $1.35 \%$.

F. The Cohesion values for group without Geo-foam with ranged between $62 \mathrm{kPa}$ and $105 \mathrm{kPa}$ at CBPD between $3.88 \%$ and $18.63 \%$.

G. The Cohesion values for group with Geo-foam with ranged between $50 \mathrm{kPa}$ and $20 \mathrm{kPa}$ at Geo-foam between $0.32 \%$ and $1.35 \%$.

H. The friction angle of group without Geo-foam with ranged between $30^{\circ}$ and $11^{\circ}$ at CBPD between $3.88 \%$ and $18.63 \%$.

I. The friction angle of group with Geo-foam with ranged between $10^{\circ}$ and $22^{\circ}$ at CBPD between $0.32 \%$ and $1.35 \%$.

\section{References}

1. Baghdadi ZA, Fartani MN, Sabban NA (1995) Soil Modification by Cement Kiln Dust. Journal of Materials in Civil Engineering 7: 218-222. 


\section{Civil Engineering Research Journal}

2. ACI Comittee 229 (1999) Controlled Low-Strength Materials (CLSM) Report 229 R, American Concrete Institute, Farmington Hills, Mich, USA.

3. Howard AK, Hitch JL. (1998) The Design and Application of Controlled Low-Strength Materials (Flowable Fill)

4. Shaheen AF (1993) Stabilization of Clayey Sub-grade Soil Using ByPass Dust. M Sc Thesis, Faculty of Engineering Cairo University, Egypt.

5. El-Didamony H, Abo El-Enein AA, Ali AH, Sokkary TM (1997) Recycling of cement kiln dust in slag cement. Proceeding of the $7^{\text {th }}$ International Conference on Environment Protection, May 20-22 Alexandria, Egypt, pp. 587-603.

6. (1986) AASHTO 1986 Guide for Design of Pavement Structures American Association of State Highway and Transportation Officials, Washington DC, USA.
7. Abichou TH, Benson CH, Edil TB (1997) Database on Beneficial Reuse of Foundry By-Products. Environmental Geotechnical report. Dept of Civil Environmental Engineering, University of Wisconsin, Madison, Wisconsin.

8. Al-Jabri, Khalifa (2002) Use of Cement By-pass Dust in Flowable Fill Mixtures. Cement Concrete and Aggregates 24(2): 2002.

9. Collins RJ, Emery JJ (1983) Kiln Dust-Fly Ash Systems for Highway Bases and Subbases. Federal Highway Administration, Report No FHWA/RD-82/167, Washington, DC, USA.

10. Morsi MM (1997) Utilization of The Industrial Waste (By-Bass Cement Dust) in Production of Economical Materials as a Method for Environmental Protection. First International Conference \& Trade Fair on Environmental Management \& Technology.

\section{Your next submission with Juniper Publishers will reach you the below assets}

- Quality Editorial service

- Swift Peer Review

- Reprints availability

- E-prints Service

- Manuscript Podcast for convenient understanding

- Global attainment for your research

- Manuscript accessibility in different formats

( Pdf, E-pub, Full Text, Audio)

- Unceasing customer service

Track the below URL for one-step submission https://juniperpublishers.com/online-submission.php 